\title{
Ants (Hymenoptera: Formicidae) in different green areas in the metropolitan region of Salvador, Bahia state, Brazil
}

\author{
T. S. Melo a,b,c* (D), E. B. A. Kocha, (iD, A. R. S. Andrade a,b,c (D), M. L. O. Travassos a,b,c (D) M. C. L. Peres ${ }^{\mathrm{a}}$ (D) \\ and J. H. C. Delabie a,b (iD) \\ aUniversidade Federal da Bahia - UFBA, Programa de Pós-graduação em Ecologia, Salvador, BA, Brasil \\ 'Laboratório de Mirmecologia, Convênio entre Comissão Executiva do Plano da Lavoura Cacaueira - CEPLAC e Universidade Estadual \\ de Santa Cruz - UESC, Ilhéus, BA, Brasil \\ 'Universidade Católica do Salvador - UCSal, Centro de Ecologia e Conservação Animal, Salvador, BA, Brasil
}

One of the main causes for biodiversity loss is urbanization, mostly due to city growth in highly diverse areas and priority conservation areas, such as the Atlantic Forest (Brasil, 2002; Melo and Delabie, 2017; Conservation International, 2019). Some of the major motivations for the conservation of urban biodiversity, include the preservation of local diversity, the protection of important populations and rare species, as well as the provision of ecosystem services (Dearborn and Kark, 2010). To achieve this, it is essential to understand species diversity and distribution in urban areas.

In urban environments, green areas are important habitats for conservation as they house a large number of species (Nielsen et al., 2014; Melo and Delabie, 2017). With more than 16 thousand species/morph species of described ants (Bolton, 2019), data on ants in urban environments has increased worldwide over the last 20 years, with the majority of studies being focused on species distribution (Santos, 2016). In Brazil, more than 490 ant species have been recorded in urban green areas (Melo and Delabie, 2017), with a large number of species being registered in the city of Salvador, Bahia (Melo et al., 2014; Melo and Delabie, 2017). Thus, with the aim of increasing the available knowledge on the ant species from Salvador, recorded by Melo et al. (2014), we present an ant checklist with additional data for their occurrence in green areas.

Ants were collected in Salvador, Bahia, Brazil ( $12^{\circ} 58^{\prime} \mathrm{S} 38^{\circ} 30^{\prime} \mathrm{W}$ ), between April and June 2019 at 62 sample points (SP). At each sample point we removed an area of leaf litter of size $50 \times 50 \mathrm{~cm}$ and installed a bait line as described below. Four green area categories were sampled: fragment (25 samples), road median strip (18), squares (13) and vacant lots (6), totaling 62 samples (Table 1 ). The SPs were at least 100 meters apart. At each SP we sampled the leaf litter and plants to ensure the detection of ant diversity. To sample the leaf litter fauna, we used a Winkler extractor in units of $50 \times 50 \mathrm{~cm}$, where we left the collected material exposed for $24 \mathrm{~h}$ for fauna extraction. We collected the vegetation fauna in arboreal strata with the adapted bait line technique (Leponce et al., 2019). This technique consists of putting a rope over the top of a tree, using a slingshot. We allocated baits every two meters along the rope from one meter above soil level to the highest tree point, and left them for three hours. We conducted surveys with authorization licenses no ${ }^{2} 62268$-1 from MMA/SISBIO and no 2018-003254/TEC/PESQ-0006 from INEMA/DIRUC. The identification of morph species was acheived following Melo et al. (2014) and species nomenclature followed Bolton (2019). Ants were deposited in the collection of the Laboratório de Mirmecologia (CPDC, curator: J. Delabie), at the Comissão Executiva do Plano da Lavoura Cacaueira (CEPLAC, Itabuna, Bahia, Brazil), voucher \#5846. We evaluated the variation in ant species richness according to the type of sampling method and the different types of green areas sampled. Additionally, we measured the similarity between green area types (fragment, road median strip, public square and vacant lots), and we used a Permutational Analysis of Variance (PERMANOVA), with Jaccard's similarity index as the association measure to evaluate differences in ant species composition. Rarefaction curves and Non-Metric Multidimensional Scaling (NMDS, Jaccard's distance) were produced in order to compare the richness between the environments. The statistical analyzes were performed using PAST 4.02 software (Hammer et al., 2001).

We collected 93 ant species/morph species of 39 genera and six subfamilies (Table 2). Myrmicinae was the richest ( $S=57$ species), followed by Ponerinae $(S=12)$, Formicinae $(S=9)$, Dolichoderinae $(S=7)$, Pseudomyrmecinae $(S=4)$, Ectatomminae ( $S=3)$, and Amblyoponinae $(S=1)$. In Brazil, Melo and Delabie (2017) found a high number of species in urban environments from Atlantic Forest.

Five cities in the metropolitan region of Salvador (Bahia, S = 198 species) (Melo et al., 2014), ten cities in an inland city in Santa Catarina $(S=140)$ (Lutinski et al., 2013), three cities at Alto Tietê (São Paulo, S = 86) (Munhae et al., 2009), and the city of São Paulo (São Paulo, S = 79) (Morini et al., 2007), presented the same number of species found in this study, even

*e-mail: terciosilvamelo@hotmail.com

Received: April 7, 2020 - Accepted: July 23, 2020 
Table 1. Description of green areas sampled and sampling effort in the city of Salvador, Bahia, Brazil.

\begin{tabular}{llc}
\hline \multicolumn{1}{c}{ Green area } & \multicolumn{1}{c}{ Characteristics } & Number of samples \\
\hline Fragment & $\begin{array}{l}\text { Natural environment, without environmental management and with canopy } \\
\text { formation }\end{array}$ & 25 \\
Road median strip & $\begin{array}{l}\text { Artificial environment located on the side of streets, under environmental } \\
\text { management and without canopy formation }\end{array}$ & 18 \\
Public square & $\begin{array}{l}\text { Artificial environment used for recreation, under environmental management } \\
\text { and without canopy formation }\end{array}$ & 13 \\
Vacant lots & $\begin{array}{l}\text { Artificial environment without human use, environmental management } \\
\text { and canopy formation }\end{array}$ & 6 \\
\hline
\end{tabular}

Table 2. List of ant species collected in the city of Salvador, Bahia, Brazil, between April and June of 2019.

\begin{tabular}{|c|c|c|c|}
\hline Subfamily & \multirow{2}{*}{$\begin{array}{l}\text { Sampling } \\
\text { technique }\end{array}$} & \multirow{2}{*}{ Habitat } & \multirow{2}{*}{ Occurrence (\%) } \\
\hline Specie & & & \\
\hline \multicolumn{4}{|c|}{ Amblyoponinae } \\
\hline Prionopelta antillana Forel, 1909 * & W & $\mathrm{R}, \mathrm{F}$ and $\mathrm{S}$ & 6.45 \\
\hline \multicolumn{4}{|c|}{ Dolichoderinae } \\
\hline Azteca prox. alfari ${ }^{*}$ & B & F and $S$ & 3.22 \\
\hline Azteca severini Emery, 1896 * & B & F and $S$ & 3.22 \\
\hline Dolichoderus smithi MacKay, 1993 * & W & S & 1.61 \\
\hline Dorymyrmex pyramicus (Roger, 1863)* & B & $\mathrm{R}, \mathrm{F}$ and $\mathrm{S}$ & 19.35 \\
\hline Dorymyrmex sp.1 & B & $\mathrm{R}$ and $\mathrm{S}$ & 3.22 \\
\hline Linepithema neotropicum Wild, 2007 & B & $\mathrm{R}, \mathrm{F}$ and $\mathrm{V}$ & 6.45 \\
\hline Tapinoma melanocephalum (Fabricius, 1793) & B and $\mathrm{W}$ & $\mathrm{R}, \mathrm{F}$ and $\mathrm{S}$ & 22.58 \\
\hline \multicolumn{4}{|c|}{ Ectatomminae } \\
\hline Ectatomma brunneum Smith, 1858 * & W & $\mathrm{F}$ & 1.61 \\
\hline Ectatomma edentatum Roger, $1863^{*}$ & $\mathrm{~W}$ & $\mathrm{R}$ and $\mathrm{F}$ & 12.9 \\
\hline Ectatomma tuberculatum (Olivier, 1792) & B & $\mathrm{F}$ & 11.29 \\
\hline \multicolumn{4}{|c|}{ Formicinae } \\
\hline Brachymyrmex admotus Mayr, 1887 * & $\mathrm{B}$ and $\mathrm{W}$ & $\mathrm{R}, \mathrm{F}, \mathrm{S}$ and $\mathrm{V}$ & 29.03 \\
\hline Brachymyrmex heeri Forel, 1874 & B and $\mathrm{W}$ & $\mathrm{R}, \mathrm{F}$ and $\mathrm{V}$ & 11.29 \\
\hline Camponotus blandus (Smith, 1858) & B and $\mathrm{W}$ & F, S and V & 4.83 \\
\hline Camponotus fastigatus Roger, 1863 & B and $\mathrm{W}$ & $\mathrm{R}, \mathrm{F}$ and $\mathrm{V}$ & 16.12 \\
\hline Camponotus novogranadensis Mayr, 1870 & B and $\mathrm{W}$ & $\mathrm{R}$ and $\mathrm{V}$ & 4.83 \\
\hline Camponotus vittatus Forel, 1904 & $B$ and $W$ & $\mathrm{~F}$ & 3.22 \\
\hline Myrmelachista sp. ${ }^{*}$ & B & $\mathrm{R}$ & 1.61 \\
\hline Nylanderia fulva (Mayr, 1862) * & W & $\mathrm{F}$ and $\mathrm{V}$ & 4.83 \\
\hline Paratrechina longicornis (Latreille, 1802) & $\mathrm{B}$ and $\mathrm{W}$ & $\mathrm{R}, \mathrm{F}, \mathrm{S}$ and $\mathrm{V}$ & 12.9 \\
\hline \multicolumn{4}{|c|}{ Myrmicinae } \\
\hline Acromyrmex balzani (Emery, 1890)* & $\mathrm{W}$ & $\mathrm{F}$ & 1.61 \\
\hline Acromyrmex rugosus (Smith, 1858) & $\mathrm{B}$ and $\mathrm{W}$ & $\mathrm{R}$ and $\mathrm{S}$ & 4.83 \\
\hline Acromyrmex subterraneus brunneus (Forel, 1912) & W & $\mathrm{F}$ & 4.83 \\
\hline Basiceros scambognathus (Brown, 1949) * & W & $\mathrm{F}$ & 3.22 \\
\hline
\end{tabular}

*New record for Salvador. Occurrence $=$ percentage of each species in the sample points; $\mathrm{B}=$ Bait line; $\mathrm{W}=\mathrm{Winkler}$ extractor; $\mathrm{F}=\mathrm{Fragment}$; $\mathrm{R}=$ Road median strip; $\mathrm{S}=$ Public square; $\mathrm{V}=$ Vacant lots. 
Table 2. Continued...

\begin{tabular}{|c|c|c|c|}
\hline Subfamily & \multirow{2}{*}{$\begin{array}{l}\text { Sampling } \\
\text { technique }\end{array}$} & \multirow{2}{*}{ Habitat } & \multirow{2}{*}{ Occurrence (\%) } \\
\hline Specie & & & \\
\hline \multicolumn{4}{|c|}{ Myrmicinae } \\
\hline Cardiocondyla obscurior Wheeler, 1929 & $\mathrm{~B}$ and $\mathrm{W}$ & $\mathrm{R}$ and $\mathrm{S}$ & 8.06 \\
\hline Carebara sp.1 & W & $\mathrm{F}$ & 3.22 \\
\hline Carebara sp. $2^{*}$ & W & $\mathrm{S}$ & 1.61 \\
\hline Cephalotes atratus (Linnaeus, 1758) * & B & $\mathrm{F}$ & 1.61 \\
\hline Cephalotes maculatus (Smith, 1876) * & $\mathrm{W}$ & $\mathrm{F}$ & 1.61 \\
\hline Cephalotes minutus (Fabricius, 1804) & $\mathrm{B}$ and $\mathrm{W}$ & $\mathrm{R}$ and $\mathrm{S}$ & 3.22 \\
\hline Crematogaster erecta Mayr, 1866 & B & $\mathrm{R}, \mathrm{F}$ and $\mathrm{V}$ & 16.12 \\
\hline Crematogaster limata Smith, 1858 & B and $\mathrm{W}$ & $\mathrm{R}$ and $\mathrm{F}$ & 11.29 \\
\hline Crematogaster victima Smith, 1858 & $\mathrm{~B}$ and $\mathrm{W}$ & $\mathrm{R}, \mathrm{F}$ and $\mathrm{S}$ & 8.06 \\
\hline Cyphomyrmex rimosus (Spinola, 1851) & W & $\mathrm{R}$ and $\mathrm{F}$ & 6.45 \\
\hline Cyphomyrmex transversus Emery, 1894 & W & $\mathrm{R}, \mathrm{F}, \mathrm{S}$ and $\mathrm{V}$ & 8.06 \\
\hline Megalomyrmex drifti Kempf, 1961 * & W & $\mathrm{F}$ & 1.61 \\
\hline Monomorium floricola (Jerdon, 1851) & $\mathrm{B}$ and $\mathrm{W}$ & $\mathrm{R}, \mathrm{F}, \mathrm{S}$ and $\mathrm{V}$ & 48.38 \\
\hline Mycetomoellerius sp.1 & W & $\mathrm{R}$ and $\mathrm{F}$ & 9.67 \\
\hline Mycetomoellerius sp.2 & B & $\mathrm{R}$ & 1.61 \\
\hline Mycocepurus goeldii (Forel, 1893) & W & $\mathrm{R}$ and $\mathrm{F}$ & 6.45 \\
\hline Octostruma balzani (Emery, 1894) & W & $\mathrm{F}$ & 1.61 \\
\hline Octostruma iheringi (Emery, 1894) & W & $\mathrm{F}$ & 6.45 \\
\hline Paratrachymyrmex sp.2* & W & $\mathrm{F}$ & 1.61 \\
\hline Pheidole (complex flavens) sp.2 & $\mathrm{B}$ and $\mathrm{W}$ & $\mathrm{R}, \mathrm{F}$ and $\mathrm{S}$ & 17.74 \\
\hline Pheidole (group diligens) sp.27 & W & $\mathrm{F}$ & 1.61 \\
\hline Pheidole (group fallax) sp.13 & $\mathrm{B}$ and $\mathrm{W}$ & $\mathrm{R}$ and $\mathrm{F}$ & 4.83 \\
\hline Pheidole (group fallax) sp.6 & $\mathrm{B}$ and $\mathrm{W}$ & $\mathrm{F}$ & 8.06 \\
\hline Pheidole (group fallax) sp.8 & $\mathrm{B}$ and $\mathrm{W}$ & $\mathrm{R}, \mathrm{F}$ and $\mathrm{S}$ & 11.29 \\
\hline Pheidole (group flavens) sp.21 & $\mathrm{B}$ and $\mathrm{W}$ & $\mathrm{R}$ and $\mathrm{F}$ & 8.06 \\
\hline Pheidole (group flavens) sp.23 & $\mathrm{B}$ and $\mathrm{W}$ & $\mathrm{R}, \mathrm{F}$ and $\mathrm{V}$ & 11.29 \\
\hline Pheidole megacephala (Fabricius, 1793)* & $\mathrm{B}$ and $\mathrm{W}$ & $\mathrm{R}, \mathrm{F}, \mathrm{S}$ and $\mathrm{V}$ & 59.67 \\
\hline Pheidole obscurithorax Naves, 1985 & $\mathrm{~B}$ and $\mathrm{W}$ & $\mathrm{R}$ and $\mathrm{V}$ & 3.22 \\
\hline Pheidole radoszkowskii Mayr, 1884 & $\mathrm{~B}$ and $\mathrm{W}$ & F and $\mathrm{S}$ & 17.74 \\
\hline Pheidole synarmata Wilson, 2003 & W & S & 1.61 \\
\hline Rogeria foreli Emery, $1894^{*}$ & W & F and $\mathrm{V}$ & 3.22 \\
\hline Rogeria sp. $1^{*}$ & W & $\mathrm{F}$ & 1.61 \\
\hline Rogeria subarmata (Kempf, 1961) * & B & $\mathrm{F}$ & 1.61 \\
\hline Sericomyrmex bondari Borgmeier, 1937 * & W & $\mathrm{F}$ & 1.61 \\
\hline Solenopsis geminata (Fabricius, 1804) & W & $\mathrm{R}, \mathrm{F}$ and $\mathrm{S}$ & 8.06 \\
\hline Solenopsis globularia (Smith, 1858) & W & $\mathrm{R}, \mathrm{S}$ and $\mathrm{V}$ & 6.45 \\
\hline Solenopsis pollux Forel, 1893 * & B and $\mathrm{W}$ & R, F, S and V & 11.29 \\
\hline Solenopsis saevissima (Smith, 1855)* & $\mathrm{B}$ and $\mathrm{W}$ & $\mathrm{R}$ and $\mathrm{V}$ & 3.22 \\
\hline Solenopsis sp.1 & $\mathrm{B}$ and $\mathrm{W}$ & $\mathrm{R}, \mathrm{F}, \mathrm{S}$ and $\mathrm{V}$ & 56.45 \\
\hline Solenopsis sp.2 & W & F and $S$ & 17.74 \\
\hline
\end{tabular}

${ }^{*}$ New record for Salvador. Occurrence = percentage of each species in the sample points; $\mathrm{B}=$ Bait line; $\mathrm{W}=$ Winkler extractor; $\mathrm{F}=$ Fragment; $\mathrm{R}=$ Road median strip; $\mathrm{S}=$ Public square; $\mathrm{V}=$ Vacant lots. 
Table 2. Continued...

\begin{tabular}{|c|c|c|c|}
\hline Subfamily & \multirow{2}{*}{$\begin{array}{l}\text { Sampling } \\
\text { technique }\end{array}$} & \multirow{2}{*}{ Habitat } & \multirow{2}{*}{ Occurrence (\%) } \\
\hline Specie & & & \\
\hline \multicolumn{4}{|c|}{ Myrmicinae } \\
\hline Solenopsis sp.4 & W & $\mathrm{F}$ & 3.22 \\
\hline Solenopsis sp.6 & W & $\mathrm{F}$ & 1.61 \\
\hline Strumigenys carinithorax Borgmeier, $1934^{*}$ & W & $\mathrm{R}, \mathrm{F}, \mathrm{S}$ and $\mathrm{V}$ & 33.87 \\
\hline Strumigenys denticulata Mayr, 1887 & W & $\mathrm{F}, \mathrm{S}$ and $\mathrm{V}$ & 22.58 \\
\hline Strumigenys precava Brown, $1954^{*}$ & W & $\mathrm{F}$ & 6.45 \\
\hline Strumigenys subedentata Mayr, 1887 & W & $\mathrm{F}$ & 1.61 \\
\hline Tetramorium bicarinatum (Nylander, 1846) & B & $\mathrm{R}$ & 1.61 \\
\hline Tetramorium lucayanum (Latreille, 1802) & $\mathrm{B}$ and $\mathrm{W}$ & $\mathrm{F}, \mathrm{S}$ and $\mathrm{V}$ & 6.45 \\
\hline Tetramorium simillimum (Smith, 1851) & W & $R$ and $S$ & 6.45 \\
\hline Wasmannia auropunctata (Roger, 1863) & $\mathrm{B}$ and $\mathrm{W}$ & $\mathrm{R}, \mathrm{F}$ and $\mathrm{V}$ & 24.19 \\
\hline Wasmannia rochai Forel, 1912 & $\mathrm{~B}$ and $\mathrm{W}$ & F and $S$ & 4.83 \\
\hline Wasmannia sp.1 * & W & $\mathrm{F}$ & 1.61 \\
\hline Xenomyrmex sp.1* & B & $\mathrm{F}$ & 3.22 \\
\hline
\end{tabular}

\begin{tabular}{|c|c|c|c|}
\hline \multicolumn{4}{|c|}{ Ponerinae } \\
\hline Anochetus diegensis Forel, 1912 * & $\mathrm{W}$ & $\mathrm{R}, \mathrm{F}, \mathrm{S}$ and $\mathrm{V}$ & 11.29 \\
\hline Hypoponera sp.1 & W & $\mathrm{F}$ & 8.06 \\
\hline Hypoponera sp.2 & W & $\mathrm{F}$ & 6.45 \\
\hline Hypoponera sp.3 & W & $\mathrm{R}, \mathrm{F}, \mathrm{S}$ and $\mathrm{V}$ & 16.12 \\
\hline Hypoponera sp.4 & W & $\mathrm{R}$ and $\mathrm{F}$ & 11.29 \\
\hline Hypoponera sp.5 & W & $\mathrm{F}$ & 3.22 \\
\hline Leptogenys pusilla (Emery, 1890)* & W & $\mathrm{F}$ & 1.61 \\
\hline Odontomachus bauri Emery, 1892 & W & S & 1.61 \\
\hline Odontomachus haematodus (Linnaeus, 1758) & B and $\mathrm{W}$ & $\mathrm{F}$ & 3.22 \\
\hline Odontomachus meinerti Forel, 1905 & W & $\mathrm{F}$ & 3.22 \\
\hline Pachycondyla harpax (Fabricius, 1804) & $\mathrm{W}$ & $\mathrm{V}$ & 1.61 \\
\hline Thaumatomyrmex sp. $1 *$ & W & $\mathrm{F}$ & 1.61 \\
\hline \multicolumn{4}{|c|}{ Pseudomyrmecinae } \\
\hline Pseudomyrmex (group pallidus) sp. $5^{*}$ & B & $\mathrm{F}$ & 1.61 \\
\hline Pseudomyrmex curacaensis (Forel, 1912)* & B & S & 1.61 \\
\hline Pseudomyrmex gracilis (Fabricius, 1804) & B & F and $S$ & 3.22 \\
\hline Pseudomyrmex schuppi (Forel, 1901) * & $\mathrm{B}$ and $\mathrm{W}$ & $\mathrm{R}$ and $\mathrm{S}$ & 3.22 \\
\hline RICHNESS & & 93 & \\
\hline
\end{tabular}

${ }^{*}$ New record for Salvador. Occurrence = percentage of each species in the sample points; $\mathrm{B}=$ Bait line; $\mathrm{W}=\mathrm{Winkler}$ extractor; $\mathrm{F}=$ Fragment; $\mathrm{R}=$ Road median strip; $\mathrm{S}=$ Public square; $\mathrm{V}=$ Vacant lots.

when implementing different sampling techniques and efforts. In these cities, representatives of Myrmicinae were found to have the highest richness followed by Formicinae and Ponerinae (Morini et al., 2007; Munhae et al., 2009; Lutinski et al., 2013; Melo et al., 2014). Melo et al. (2014) recorded 164 species in the city of Salvador however, we reported 34 new species, increasing the number of ant species in Salvador urban green areas to 198 .
A higher number of species was found in the leaf litter (Winkler extractor, $\mathrm{S}=77 ; 46$ exclusive species) than in the vegetation (bait line, $S=47 ; 16$ exclusive species). Ant assemblage composition shows important differences according to strata (mostly in soil when compared to vegetation) (Wilson and Hölldobler, 2005). Thus, a lower richness of arboreal species is expected as evolutionary history shows that ground ants specialize in resource selection, nesting places, and dispersal mechanisms and 
therefore, have an advantage when compared to vegetation assemblages (generalists) (Wilson and Hölldobler, 2005). The sampling technique may be related to the lower arboreal richness observed, since baits can attract only a proportion of ant assemblies. Despite the recorded arboreal ant richness, nine new species were sampled: Azteca prox. alfari, A. severini Emery, 1896, Cephalotes atratus (Linnaeus, 1758), Dorymyrmex pyramicus (Roger, 1863), Myrmelachista sp.1, Pseudomyrmex sp.5 (group pallidus), P. curacaensis (Forel, 1912), Rogeria subarmata (Kempf, 1961) and Xenomyrmex sp.1.

Among the different types of green urban areas, forest fragments showed higher richness $(S=74$ species; 32 exclusive species), followed by road median strips ( $S=44$; three exclusives), squares ( $S=37$; five exclusives), and vacant lots ( $S=26$; one exclusive) (Figure 1 and 2 ). We detected significant differences in ant species composition according to the type of green areas $\left(F_{3,58}=2.07 ; p<0.001\right)$. Ant assemblages from road median strips and public squares were $42 \%$ more similar and $35 \%$ of those were similar to ants from vacant lots (Figure 3). Ants from forest fragments were $30 \%$ similar to all other green urban areas here studied. We recorded 10 species common to all green areas: Anochetus diegensis Forel, 1912, Brachymyrmex admotus Mayr, 1887, Cyphomyrmex transversus Emery, 1894, Hypoponera sp.3, Monomorium floricola (Jerdon, 1851), Paratrechina longicornis (Latreille, 1802), Pheidole megacephala (Fabricius, 1793), Solenopsis pollux Forel, 1893, Solenopsis sp.1 and Strumigenys carinithorax Borgmeier, 1934 (Table 2). A high richness of native ants has been reported in cities with different levels of anthropogenic disturbance (Santos, 2016; Melo and Delabie, 2017). Conserved environments, such as native fragments, have higher ant species richness

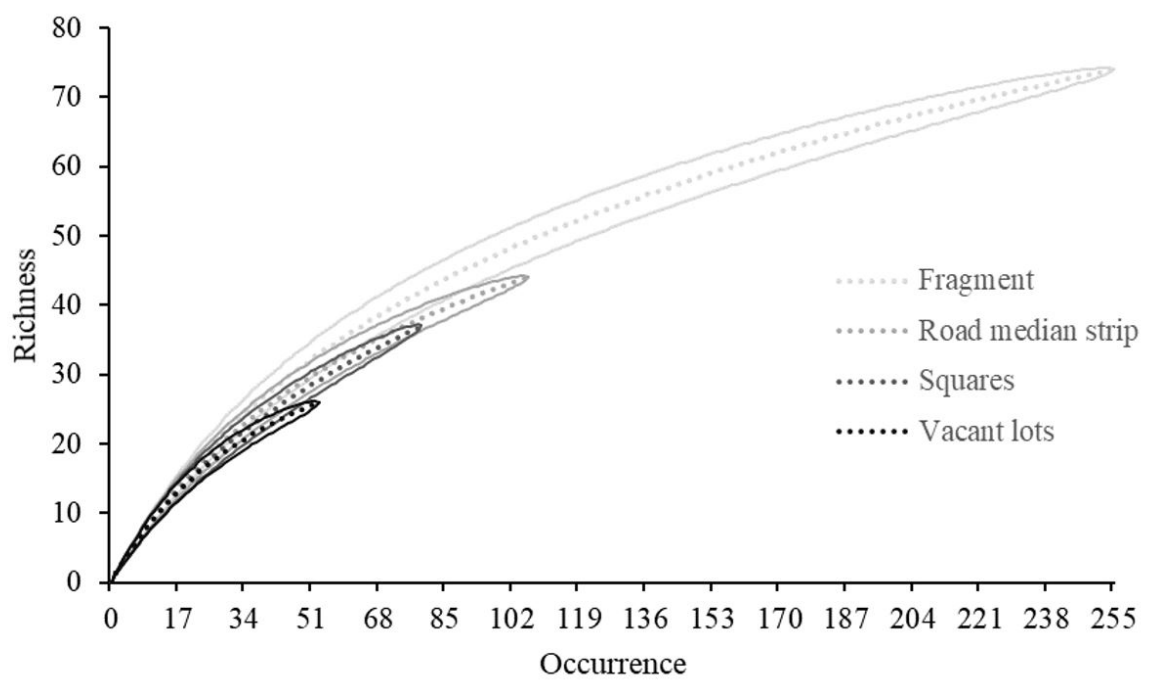

Figure 1. Rarefaction curve (dotted line) comparing the ant richness of different green areas studied in Salvador, Bahia, Brazil. Continuous line: confidence interval.

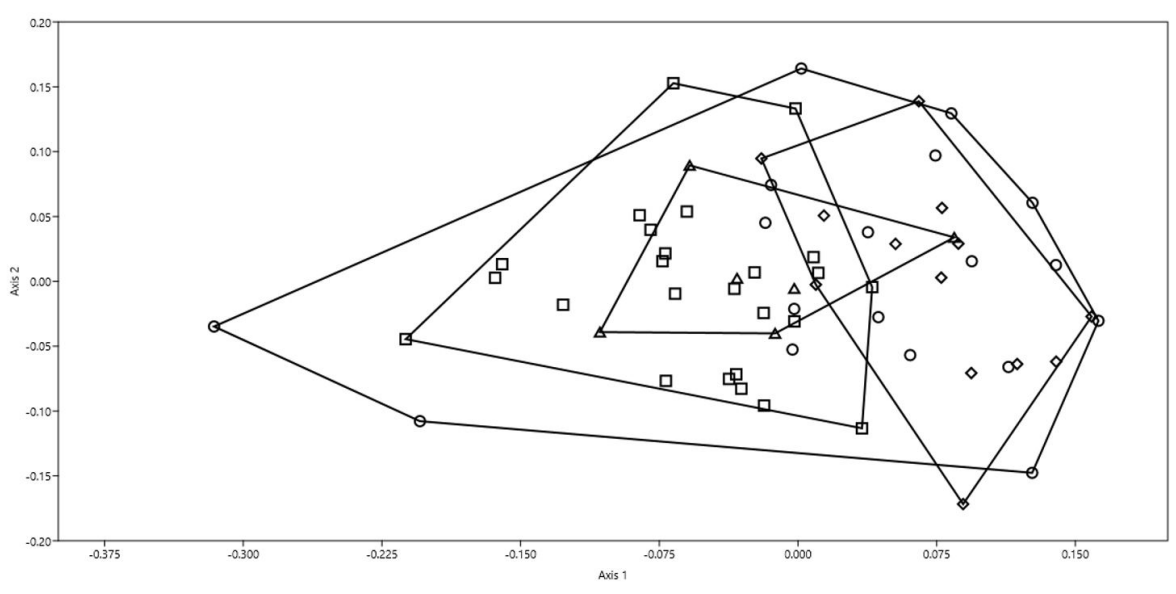

Figure 2. Distribution of the ant assemblages found in different green areas in Salvador, Bahia, Brazil. Circle = Road median strip; Square $=$ Fragment; Diamond $=$ Public square; Triangle $=$ Vacant lots . 


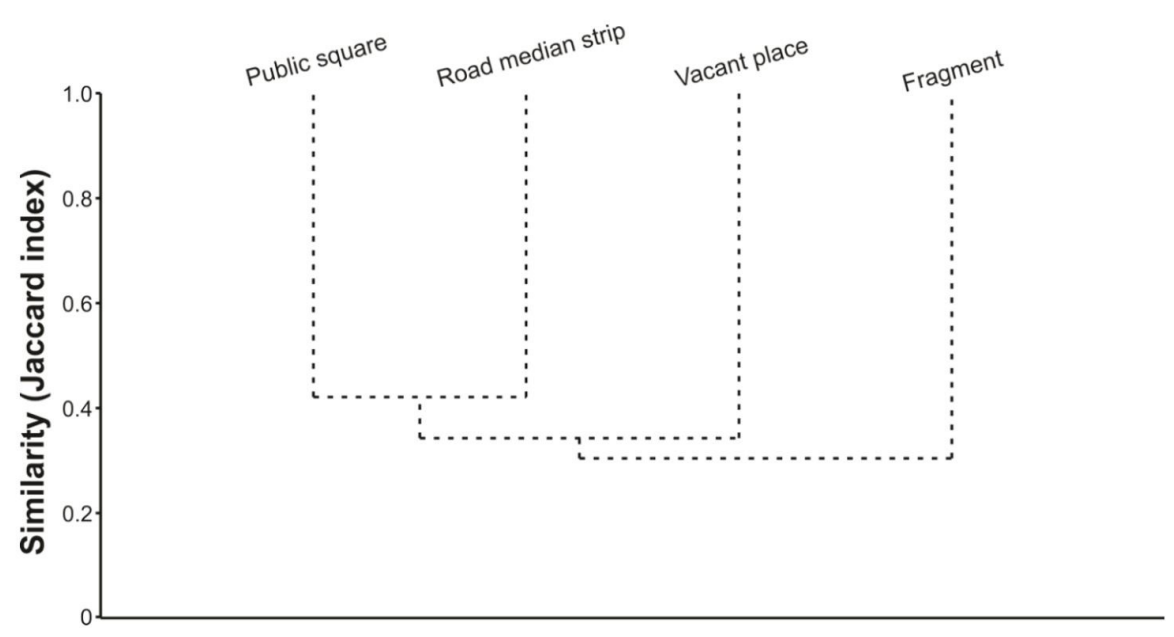

Figure 3. Comparison of the ant assemblages found in different green areas in Salvador, Bahia, Brazil, through a similarity dendrogram.

compared to impacted ones such as road median strips, public squares, and vacant lots (Melo and Delabie, 2017). Therefore, we highlight the importance of maintaining more conserved green areas in order to preserve ant species. Although additional research and methods would allow for the detection of more ant species, this study has deepened the knowledge available on ants from Salvador.

\section{Acknowledgements}

Thanks are given to the Ministério do Meio Ambiente - MMA and Instituto do Meio Ambiente e Recursos Hídricos - INEMA for the collection permits, to Icaro Silva e Mendonça and Lais Leal Lopes for reviewing the English text and anonymous reviewers for contributions. TSM thanks CAPES for the scholarship provided and JHCD acknowledges his research grant from $\mathrm{CNPq}$ (process 304629/2018-9).

\section{References}

BOLTON, B. 2019 [viewed 11 November 2019]. AntWeb: versão 8.6.6 [software]. Available from: http://www.antweb.org

BRASIL. Ministério do Meio Ambiente - MMA, 2002. Biodiversidade brasileira: avaliação e identificação de áreas e ações prioritárias para conservação, utilização sustentável e repartição dos benefícios da biodiversidade nos biomas brasileiros. Brasília: Secretaria de Biodiversidade e Florestas, $404 \mathrm{p}$.

CONSERVATION INTERNATIONAL, 2019 [viewed 12 December 2019]. Biodiversity hotspots [online]. Available from: https://www. conservation.org/priorities/biodiversity-hotspots

DEARBORN, D.C. and KARK, S., 2010. Motivations for conserving urban biodiversity. Conservation Biology, vol. 24, no. 2, pp. 432-440. http://dx.doi.org/10.1111/j.1523-1739.2009.01328.x. PMid: 19775276.

HAMMER, O., HARPER, D.A.T. and RYAN, P.D., 2001. PAST: paleontological statistics software package for education and data analysis. Palaeontologia Electronica, vol. 4, no. 1, pp. 9p.
LEPONCE, M., DELABIE, J.H.C., ORIVEL, J., JACQUEMIN, J., CALVOMARTIN, M. and DEJEAN, A., 2019. Tree-dwelling ant survey (Hymenoptera, Formicidae) in Mitaraka, French Guiana. Zoosystema, vol. 41, no. 10, pp. 163-179. http://dx.doi. org/10.5252/zoosystema2019v41a10.

LUTINSKI, J.A., LOPES, B.C. and MORAIS, A.B.B., 2013. Diversidade de formigas urbanas (Hymenoptera: Formicidae) de dez cidades do sul do Brasil. Biota Neotropica, vol. 13, no. 3, pp. 332-342. http://dx.doi.org/10.1590/S1676-06032013000300033.

MELO, T.S. and DELABIE, J.H.C., 2017. Ecologia e conservação da biodiversidade de formigas em ambientes urbanos. In: O.C. BUENO, A.E.C. CAMPOS and M.S.C. MORINI, eds. Formigas em ambientes urbanos no Brasil. Bauru: Canal 6, pp. 189-240.

MELO, T.S., PERES, M.C.L., CHAVARI, J.L., BRESCOVIT, A.D. and DELABIE, J.H.C., 2014. Ants (Formicidae) and Spiders (Araneae) listed from the Metropolitan Region of Salvador, Brazil. Check List, vol. 10, no. 2, pp. 355-365. http://dx.doi.org/10.15560/10.2.355.

MORINI, M.S.C., MUNHAE, C.B., LEUNG, R., CANDIANI, D.F. and VOLTOLINI, J.C., 2007. Comunidades de formigas (Hymenoptera, Formicidae) em fragmentos de Mata Atlântica situados em áreas urbanizadas. Iheringia, vol. 97, no. 3, pp. 246-252. http:// dx.doi.org/10.1590/S0073-47212007000300005.

MUNHAE, C.B., BUENO, Z.F.N., MORINI, M.S.C. and SILVA, R.R., 2009. Composition of the ant fauna (Hymenoptera: Formicidae) in public squares in Southern Brazil. Sociobiology, vol. 53, no. 2, pp. 455-472.

NIELSEN, A.B., VAN DEN BOSCH, M., MARUTHAVEERAN, S. and VAN DEN BOSCH, C.K., 2014. Species richness in urban parks and its drivers: a review of empirical evidence. Urban Ecosystems, vol. 17, no. 1, pp. 305-327. http://dx.doi.org/10.1007/s11252013-0316-1.

SANTOS, M.N., 2016. Research on urban ants: approaches and gaps. Insectes Sociaux, vol. 63, no. 3, pp. 359-371. http://dx.doi. org/10.1007/s00040-016-0483-1.

WILSON, E.O. and HÖLLDOBLER, B., 2005. The rise of the ants: a phylogenetic and ecological explanation. Proceedings of the National Academy of Sciences of the United States of America, vol. 102, no. 21, pp. 7411-7414. http://dx.doi.org/10.1073/ pnas.0502264102. PMid:15899976. 